\title{
Metal-Based Biologically Active Compounds: Synthesis, Spectral, and Antimicrobial Studies of Cobalt, Nickel, Copper, and Zinc Complexes of Triazole-Derived Schiff Bases
}

\author{
Kiran Singh, ${ }^{1}$ Yogender Kumar, ${ }^{1}$ Parvesh Puri, ${ }^{1}$ Chetan Sharma, ${ }^{2}$ and Kamal Rai Aneja ${ }^{2}$ \\ ${ }^{1}$ Department of Chemistry, Kurukshetra University, Kurukshetra 136 119, India \\ ${ }^{2}$ Department of Microbiology, Kurukshetra University, Kurukshetra 136 119, India
}

Correspondence should be addressed to Kiran Singh, kiransinghkuk@yahoo.co.in

Received 19 July 2011; Accepted 20 September 2011

Academic Editor: Nick Katsaros

Copyright ( $) 2011$ Kiran Singh et al. This is an open access article distributed under the Creative Commons Attribution License, which permits unrestricted use, distribution, and reproduction in any medium, provided the original work is properly cited.

A series of cobalt, nickel, copper, and zinc complexes of bidentate Schiff bases derived from the condensation reaction of 4-amino5-mercapto-3-methyl/ethyl-1,2,4-triazole with 2,4-dichlorobenzaldehyde were synthesized and tested as antimicrobial agents. The synthesized Schiff bases and their metal complexes were characterized with the aid of elemental analyses, magnetic moment measurements, spectroscopic and thermogravimetric techniques. The presence of coordinated water in metal complexes was supported by infrared and thermal gravimetric studies. A square planar geometry was suggested for $\mathrm{Cu}$ (II) and octahedral geometry proposed for $\mathrm{Co}(\mathrm{II}), \mathrm{Ni}(\mathrm{II})$, and $\mathrm{Zn}$ (II) complexes. The Schiff bases and their metal complexes have been screened for antibacterial (Pseudomonas aeruginosa, Bacillus subtilis) and antifungal activities (Aspergillus niger, A. flavus). The metal complexes exhibited significantly enhanced antibacterial and antifungal activity as compared to their simple Schiff bases.

\section{Introduction}

Of late due to the constant emergence of antibiotics resistance to clinically used compounds, it is the need of the hour to develop novel antibiotics classes, which eventually would target the lipoid layer of the organisms and other aspects of pathogens' life cycle. Metal complexes may be subjected for the design and synthesis of such possibilities having such biological activities [1-3]. The chemistry of Schiff bases and their structural analogues has occupied a place of considerable importance [4] as they easily form stable complexes with most transition metal ions [5, 6] and well-established biological properties. 1,2,4-triazoles nucleus and their derivatives emerge rapidly with the advances of modern heterocyclic chemistry, promising a variety of medical applications such as antibacterial, antifungal, anticancer, antitumor, anticonvulsant, anti-inflammatory, and analgesic properties [7-12]. Schiff bases of 1,2,4-triazoles find diverse applications and extensive biological activity. The incorporation of the 1,2,4triazole unit into Schiff base macrocycles is of considerable current interest as complexes of 1,2,4-triazoles are being developed for potential use in applications such as magnetic materials and photo chemically driven molecular devices [13]. Schiff bases derived from 3-substituted-4-amino-5mercapto-1,2,4-triazoles show analgesic, antimicrobial, antiinflammatory, and antidepressant activities [14].

The aim of the present study was to modify the bioactivities of 1,2,4-triazole Schiff bases and gain the relative derivatives with better curing effect, optimization of hydrophilic/lipophilic character, and improve the bioavailability by coordinating them with transition metal ions. During the course of this work, a series of cobalt, nickel, copper, and zinc complexes of bidentate Schiff bases derived from the condensation reaction of 4-amino-5-mercapto-3methyl/ethyl-1, 2, 4-triazole with 2, 4-dichlorobenzaldehyde have been synthesized. The synthesized Schiff bases and their metal complexes were characterized with the aid of elemental analyses, magnetic moment measurements, spectroscopic, and thermogravimetric techniques. The Schiff bases and their metal complexes have been screened for antibacterial (Pseudomonas aeruginosa, Bacillus subtilis) and antifungal activities (Aspergillus niger, A. flavus). 


\section{Experimental}

2.1. Materials and Methods. All the chemicals used in the present investigation were of Analytical grade and used without further purification. The metal contents were determined using standard gravimetric methods; cobalt was estimated as cobalt pyridine thiocyanate, nickel as nickel dimethylglyoximate, copper as cuprous thiocyanate, and zinc as zinc ammonium phosphate [15].

The Perfit electrical melting point apparatus is used to record melting points of the synthesized complexes and are uncorrected. Carbon, hydrogen, and nitrogen were estimated using Perkin-Elmer 2400 Elemental Analyzer at Punjab University, Chandigarh. Electronic spectra of metal complexes were recorded in DMF on a Systronics 2203 doublebeam spectrophotometer in the region $1100-200 \mathrm{~nm}$. IR spectra were recorded on a MB-3000 ABB spectrometer in $\mathrm{KBr} / \mathrm{Nujol}$ mulls in the range $4000-250 \mathrm{~cm}^{-1}$. Proton NMR spectra were recorded in DMSO- $\mathrm{d}_{6}$ on a Bruker ACF 300 spectrometer at $300 \mathrm{MHz}$ using "tetramethyl silane" as the internal standard. Magnetic moments were measured at Institute Instrumentation Centre, IIT Roorkee on vibrating sample magnetometer (Model 155). The Perkin Elmer (Pyris Diamond) instrument was used to carry out thermal analysis of metal complexes in atmospheric air at the heating rate of $10^{\circ} \mathrm{C} \mathrm{Min}^{-1}$ using a reference to alumina powder. The EPR spectrum of the copper(II) complex was recorded at SAIF, IIT, Bombay, using VARIAN E-112 Xband EPR spectrometer with cylindrical quartz sample tube operating at microwave frequency $9.5 \mathrm{GHz}$. Field calibration was checked using tetracyanoethylene (TCNE) free radical for which $g=2.0027$ at room temperature.

2.2. Syntheses. 4-Amino-5-mercapto-3-methyl-1,2,4-triazole (ammt) and 4-amino-3-ethyl-5-mercapto-1,2,4-triazole (aemt) were prepared by reported literature method [16].

2.2.1. 4-[(2,4-Dichloro-benzylidene)-amino]-5-mercapto-3methyl-1,2,4-triazole $\left(H L^{1}\right)$. An ethanolic solution $(40 \mathrm{~mL})$ of ammt $(1.08 \mathrm{~g}, 8.33 \mathrm{mmol})$ was treated with 2,4-dichlorobenzaldehyde $(1.45 \mathrm{~g}, 8.33 \mathrm{mmol})$. The reaction mixture was refluxed for $3 \mathrm{~h}$, and then the clear solution was allowed to cool to room temperature. The solid material formed was removed by filtration, washed with cold ethanol, and recrystallized from ethanol and dried (Figure 1).

m.p. $249-252^{\circ} \mathrm{C}$, (found: C, $41.78 ; \mathrm{H}, 2.78 ; \mathrm{N}, 19.46 \%$. Calcd. For $\mathrm{C}_{10} \mathrm{H}_{8} \mathrm{Cl}_{2} \mathrm{~N}_{4} \mathrm{~S}$ : C, $\left.41.82 ; \mathrm{H}, 2.81 ; \mathrm{N}, 19.51 \%\right)$; MS: $\mathrm{m} / \mathrm{z}(\mathrm{M}+1) 286.9,(\mathrm{M}-1) 284.9$.

2.2.2. 4-[(2,4-Dichloro-benzylidene)-amino]-3-ethyl-5-mercapto-1,2,4-triazole $\left(\mathrm{HL}^{2}\right)$. An ethanolic solution of aemt $(1.41 \mathrm{~g}, 9.79 \mathrm{mmol})$ was added with stirring to an ethanolic solution of 5-nitro-furfuraldehyde $(1.71 \mathrm{~g}, 9.79 \mathrm{mmol})$ and refluxed for $3 \mathrm{~h}$, and the product was filtered off, washed with ice cold ethanol, and a light yellow crystalline product was obtained after recrystallization from ethanol (Figure 1).

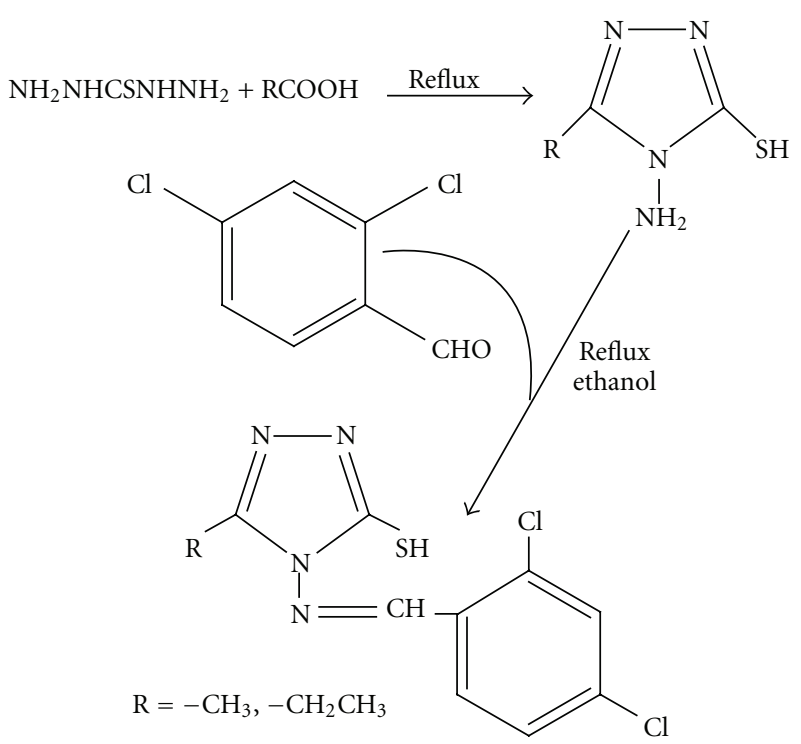

Figure 1: Scheme for the synthesis of Schiff bases.

m.p. $236-239^{\circ} \mathrm{C}$, (found: C, 43.22; H, 3.28; N, 18.43\%. calcd. For $\mathrm{C}_{11} \mathrm{H}_{10} \mathrm{Cl}_{2} \mathrm{~N}_{4} \mathrm{~S}$ : C, 43.86; H, 3.35; N, 18.60\%); MS: $\mathrm{m} / \mathrm{z}(\mathrm{M}+1) 300.9,(\mathrm{M}-1) 298.9$.

2.2.3. Syntheses of Metal Complexes of $\left[H L^{1}\right](1: 1)$. The hot ethanolic solutions of the $\mathrm{HL}^{1}(0.22 \mathrm{~g}, 0.76 \mathrm{mmol})$ were slowly added to the aqueous ethanolic solutions of acetates of $\mathrm{Co}(\mathrm{II})(0.19 \mathrm{~g}, 0.76 \mathrm{mmol}), \mathrm{Ni}(\mathrm{II})(0.19 \mathrm{~g}, 0.76 \mathrm{mmol})$, $\mathrm{Cu}$ (II) $(0.15 \mathrm{~g}, 0.76 \mathrm{mmol})$, and $\mathrm{Zn}$ (II) $(0.16 \mathrm{~g}, 0.76 \mathrm{mmol})$, which resulted in the immediate precipitation of metal derivatives. The products formed were filtered and purified by washing thoroughly with warm water, with aqueous ethanol to remove unreacted metal acetates or ligands, and finally with acetone and dried.

$\mathrm{Co}\left(\mathrm{L}^{1}\right) \mathrm{OAc} \cdot 3 \mathrm{H}_{2} \mathrm{O}$ : (found: $\mathrm{C}, 31.28 ; \mathrm{H}, 3.38 ; \mathrm{N}, 12.10$; Co, $12.78 \%$ calcd. For $\mathrm{C}_{12} \mathrm{H}_{16} \mathrm{Cl}_{2} \mathrm{CoN}_{4} \mathrm{O}_{5} \mathrm{~S}$ : C, 31.46; H, 3.52; $\mathrm{N}, 12.23$; Co, $12.86 \%)$.

$\mathrm{Ni}\left(\mathrm{L}^{1}\right) \mathrm{OAc} \cdot 3 \mathrm{H}_{2} \mathrm{O}$ : (found: $\mathrm{C}, 31.38 ; \mathrm{H}, 3.43 ; \mathrm{N}, 12.16$; $\mathrm{Ni}, 12.72 \%$ calcd. For $\mathrm{C}_{12} \mathrm{H}_{16} \mathrm{Cl}_{2} \mathrm{~N}_{4} \mathrm{NiO}_{5} \mathrm{~S}: \mathrm{C}, 31.47 ; \mathrm{H}, 3.52$; N, 12.23; Ni, 12.82\%).

$\mathrm{Cu}\left(\mathrm{L}^{1}\right) \mathrm{OAc} \cdot \mathrm{H}_{2} \mathrm{O}$ : (found: $\mathrm{C}, 39.44 ; \mathrm{H}, 2.68 ; \mathrm{N}, 16.88 ; \mathrm{Cu}$, 9.54\% calcd. For $\mathrm{C}_{12} \mathrm{H}_{12} \mathrm{Cl}_{2} \mathrm{CuN}_{4} \mathrm{O}_{3} \mathrm{~S}$ : C, 39.80; $\mathrm{H}, 2.73 ; \mathrm{N}$, $16.88 ; \mathrm{Cu}, 9.57 \%)$.

$\mathrm{Zn}\left(\mathrm{L}^{1}\right) \mathrm{OAc} \cdot 3 \mathrm{H}_{2} \mathrm{O}$ : (found: $\mathrm{C}, 30.99 ; \mathrm{H}, 3.41 ; \mathrm{N}, 11.96$; $\mathrm{Zn}, 14.00 \%$ calcd. For $\mathrm{C}_{12} \mathrm{H}_{16} \mathrm{Cl}_{2} \mathrm{~N}_{4} \mathrm{O}_{5} \mathrm{SZn}$ : C, 31.02; $\mathrm{H}, 3.47$; N, 12.06; Zn, 14.07\%).

2.2.4. Syntheses of Metal Complexes of $\left[H L^{1}\right](1: 2)$. The aqueous ethanolic solutions of acetates of $\mathrm{Co}$ (II) $(0.17 \mathrm{~g}$, $0.69 \mathrm{mmol}), \mathrm{Ni}(\mathrm{II})(0.17 \mathrm{~g}, 0.69 \mathrm{mmol}), \mathrm{Cu}(\mathrm{II}) \quad(0.14 \mathrm{~g}$, $0.69 \mathrm{mmol})$ and $\mathrm{Zn}(\mathrm{II})(0.15 \mathrm{~g}, 0.69 \mathrm{mmol})$ were treated with the hot ethanolic solutions of the $\mathrm{HL}^{1}(0.40 \mathrm{~g}, 1.39 \mathrm{mmol})$. The products formed were filtered and purified by washing thoroughly with warm water, with aqueous ethanol to remove unreacted metal acetates or ligands and finally with acetone and dried. 
$\mathrm{Co}\left(\mathrm{L}^{1}\right)_{2} \cdot 2 \mathrm{H}_{2} \mathrm{O}$ : (found: $\mathrm{C}, 35.88 ; \mathrm{H}, 2.67 ; \mathrm{N}, 16.73 ; \mathrm{Co}$, $8.80 \%$ calcd. For $\mathrm{C}_{20} \mathrm{H}_{18} \mathrm{Cl}_{4} \mathrm{CoN}_{8} \mathrm{O}_{2} \mathrm{~S}_{2}: \mathrm{C}, 36.00 ; \mathrm{H}, 2.72 ; \mathrm{N}$, 16.79; Co, 8.83\%).

$\mathrm{Ni}\left(\mathrm{L}^{1}\right)_{2} \cdot 2 \mathrm{H}_{2} \mathrm{O}$ : (found: $\mathrm{C}, 36.00 ; \mathrm{H}, 2.62 ; \mathrm{N}, 16.55 ; \mathrm{Ni}$, $8.76 \%$ calcd. For $\mathrm{C}_{20} \mathrm{H}_{18} \mathrm{Cl}_{4} \mathrm{~N}_{8} \mathrm{NiO}_{2} \mathrm{~S}_{2}$ : C, 36.01; $\mathrm{H}, 2.72 ; \mathrm{N}$, $16.80 ; \mathrm{Ni}, 8.80 \%)$.

$\mathrm{Cu}\left(\mathrm{L}^{1}\right)_{2}$ : (found: $\mathrm{C}, 33.65 ; \mathrm{H}, 2.77 ; \mathrm{N}, 13.61 ; \mathrm{Cu}, 14.77 \%$ calcd. For $\mathrm{C}_{20} \mathrm{H}_{14} \mathrm{Cl}_{4} \mathrm{CuN}_{8} \mathrm{~S}_{2}$ : C, 33.77; $\mathrm{H}, 2.83 ; \mathrm{N}, 13.63 ; \mathrm{Cu}$, $14.89 \%)$.

$\mathrm{Zn}\left(\mathrm{L}^{1}\right)_{2} \cdot 2 \mathrm{H}_{2} \mathrm{O}$ : (found: $\mathrm{C}, 35.60 ; \mathrm{H}, 2.61 ; \mathrm{N}, 16.58 ; \mathrm{Zn}$, 9.68\% calcd. For $\mathrm{C}_{20} \mathrm{H}_{18} \mathrm{Cl}_{4} \mathrm{~N}_{8} \mathrm{O}_{2} \mathrm{~S}_{2} \mathrm{Zn}$ : C, 35.65; H, 2.69; N, $16.63 ; \mathrm{Zn}, 9.71 \%)$.

2.2.5. Syntheses of Metal Complexes of $\left[\mathrm{HL}^{2}\right](1: 1)$. The hot ethanolic solutions of the $\mathrm{HL}^{2}(0.31 \mathrm{~g}, 1 \mathrm{mmol})$ were added to the aqueous ethanolic solutions of acetates of $\mathrm{Co}$ (II) $(0.25 \mathrm{~g}, 1 \mathrm{mmol}), \mathrm{Ni}(\mathrm{II})(0.25 \mathrm{~g}, 1 \mathrm{mmol}), \mathrm{Cu}(\mathrm{II})(0.20 \mathrm{~g}$, $1 \mathrm{mmol})$ and $\mathrm{Zn}$ (II) $(0.22 \mathrm{~g}, 1 \mathrm{mmol})$, which resulted in the immediate precipitation of metal derivatives. The products formed were filtered and purified by washing thoroughly with warm water, with aqueous ethanol to remove unreacted metal acetates or ligands and finally with acetone and dried.

$\mathrm{Co}\left(\mathrm{L}^{2}\right) \mathrm{OAc} \cdot 3 \mathrm{H}_{2} \mathrm{O}$ : (found: $\mathrm{C}, 33.00 ; \mathrm{H}, 3.84 ; \mathrm{N}, 11.77$; Co, $12.43 \%$ calcd. For $\mathrm{C}_{13} \mathrm{H}_{18} \mathrm{Cl}_{2} \mathrm{CoN}_{4} \mathrm{O}_{5} \mathrm{~S}$ : C, 33.07; H, 3.84; N, 11.86; Co, 12.48\%).

$\mathrm{Ni}\left(\mathrm{L}^{2}\right) \mathrm{OAc} \cdot 3 \mathrm{H}_{2} \mathrm{O}$ : (found: $\mathrm{C}, 32.97 ; \mathrm{H}, 3.81 ; \mathrm{N}, 11.81$; $\mathrm{Ni}, 12.44 \%$ calcd. For $\mathrm{C}_{13} \mathrm{H}_{18} \mathrm{Cl}_{2} \mathrm{~N}_{4} \mathrm{NiO}_{5} \mathrm{~S}$ : C, 33.08; H, 3.84; $\mathrm{N}, 11.87$; Ni, 12.44\%).

$\mathrm{Cu}\left(\mathrm{L}^{2}\right) \mathrm{OAc} \cdot \mathrm{H}_{2} \mathrm{O}$ : (found: $\mathrm{C}, 35.42 ; \mathrm{H}, 3.18 ; \mathrm{N}, 12.20 ; \mathrm{Cu}$, $14.48 \%$ calcd. For $\mathrm{C}_{13} \mathrm{H}_{14} \mathrm{Cl}_{2} \mathrm{CuN}_{4} \mathrm{O}_{3} \mathrm{~S}$ : C, 35.42; H, 3.20; N, $12.71 ; \mathrm{Cu}, 14.42 \%)$.

$\mathrm{Zn}\left(\mathrm{L}^{2}\right) \mathrm{OAc} \cdot 3 \mathrm{H}_{2} \mathrm{O}$ : (found: C, 32.60; $\mathrm{H}, 3.78 ; \mathrm{N}, 15.73$; $\mathrm{Zn}, 9.31 \%$ calcd. For $\mathrm{C}_{13} \mathrm{H}_{18} \mathrm{Cl}_{2} \mathrm{~N}_{4} \mathrm{O}_{5} \mathrm{SZn}$ : C, 32.62; H, 3.79; $\mathrm{N}, 15.97 ; \mathrm{Zn}, 9.32 \%)$.

2.2.6. Syntheses of Metal Complexes of $\left[\mathrm{HL}^{2}\right](1: 2)$. The aqueous ethanolic solutions of acetates of $\mathrm{Co}$ (II) $(0.20 \mathrm{~g}$, $0.83 \mathrm{mmol}), \mathrm{Ni}(\mathrm{II})(0.20 \mathrm{~g}, 0.83 \mathrm{mmol}), \mathrm{Cu}(\mathrm{II})(0.16 \mathrm{~g}$, $0.83 \mathrm{mmol})$, and $\mathrm{Zn}(\mathrm{II})(0.18 \mathrm{~g}, 0.83 \mathrm{mmol})$ were treated with the hot ethanolic solutions of the $\mathrm{HL}^{2}(0.50 \mathrm{~g}$, $1.6 \mathrm{mmol})$. The products formed were filtered and purified by washing thoroughly with warm water, with aqueous ethanol to remove unreacted metal acetates or ligands, and finally with acetone and dried.

$\mathrm{Co}\left(\mathrm{L}^{2}\right)_{2} \cdot 2 \mathrm{H}_{2} \mathrm{O}$ : (found: $\mathrm{C}, 37.77 ; \mathrm{H}, 3.18 ; \mathrm{N}, 16.13$; Co, $8.48 \%$ calcd. For $\mathrm{C}_{22} \mathrm{H}_{22} \mathrm{Cl}_{4} \mathrm{CoN}_{8} \mathrm{O}_{2} \mathrm{~S}_{2}: \mathrm{C}, 38.00 ; \mathrm{H}, 3.19 ; \mathrm{N}$, 16.12; Co, $8.48 \%)$.

$\mathrm{Ni}\left(\mathrm{L}^{2}\right)_{2} \cdot 2 \mathrm{H}_{2} \mathrm{O}$ : (found: $\mathrm{C}, 38.80 ; \mathrm{H}, 3.15 ; \mathrm{N}, 16.14 ; \mathrm{Ni}$, $8.45 \%$ calcd. For $\mathrm{C}_{22} \mathrm{H}_{22} \mathrm{Cl}_{4} \mathrm{~N}_{8} \mathrm{NiO}_{2} \mathrm{~S}_{2}$ : C, 38.81; H, 3.19; N, $16.12 ; \mathrm{Ni}, 8.44 \%)$.

$\mathrm{Cu}\left(\mathrm{L}^{2}\right)_{2}$ : (found: $\mathrm{C}, 39.21 ; \mathrm{H}, 2.88 ; \mathrm{N}, 16.83 ; \mathrm{Cu}, 9.55 \%$ calcd. For $\mathrm{C}_{22} \mathrm{H}_{18} \mathrm{Cl}_{4} \mathrm{CuN}_{8} \mathrm{~S}_{2}$ : C, 39.80; H, 2.73; N, 16.88; $\mathrm{Cu}$, 9.57\%).

$\mathrm{Zn}\left(\mathrm{L}^{2}\right)_{2} \cdot 2 \mathrm{H}_{2} \mathrm{O}$ : (found: C, 37.66; H, 3.15; N, 15.95; Zn, 9.32\% calcd. For $\mathrm{C}_{22} \mathrm{H}_{22} \mathrm{Cl}_{4} \mathrm{~N}_{8} \mathrm{O}_{2} \mathrm{~S}_{2} \mathrm{Zn}$ : C, 37.65; H, 3.16; N, 15.97; Zn, 9.31\%).

\subsection{Antimicrobial Assay}

2.3.1. Test Microorganisms. Four microbial strains were selected on the basis of their clinical importance in causing diseases in humans. Two bacteria (Staphylococcus aureus MTCC 96 and Bacillus subtilis MTCC 121) and two fungi, Aspergillus niger and A. flavus, the ear pathogens isolated from the patients of Kurukshetra [17], were used in the present study for evaluation of antimicrobial activity of the synthesized compounds. All the bacterial cultures were procured from Microbial Type Culture Collection (MTCC), IMTECH, Chandigarh. The bacteria were subcultured on Nutrient agar, whereas fungi on Sabouraud's dextrose agar.

2.3.2. Antibacterial Activity. The antibacterial activity of all the synthesized complexes was evaluated by using agar welldiffusion method. All the microbial cultures were adjusted to $0.5 \mathrm{McF}$ arland standard, which is visually comparable to a microbial suspension of approximately $1.5 \times 10^{8} \mathrm{cfu} / \mathrm{mL}$. $20 \mathrm{~mL}$ of Mueller Hinton agar medium was poured into each Petri plate and plates were swabbed with $100 \mu \mathrm{L}$ inocula of the test microorganisms and kept for $15 \mathrm{~min}$ for adsorption. Using sterile cork borer of $8 \mathrm{~mm}$ diameter, wells were bored into the seeded agar plates, and these were loaded with a $100 \mu \mathrm{L}$ volume with concentration of $4.0 \mathrm{mg} / \mathrm{mL}$ of each compound reconstituted in the dimethylsulphoxide (DMSO). All the plates were incubated at $37^{\circ} \mathrm{C}$ for $24 \mathrm{hrs}$. Antibacterial activity of each compound was evaluated by measuring the zone of growth inhibition against the test organisms with zone reader (HiAntibiotic zone scale). DMSO was used as a negative control whereas Ciprofloxacin was used as positive control. This procedure was performed in three replicate plates for each organism $[18,19]$.

\subsubsection{Minimum Inhibitory Concentration (MIC) Determina-} tion. MIC of all the compounds against bacterial strains was tested through a modified agar well-diffusion method [20]. In this method, a twofold serial dilution of each compound was prepared by first reconstituting the compound in DMSO followed by dilution in sterile distilled water to achieve a decreasing concentration range of 256 to $0.5 \mu \mathrm{g} / \mathrm{mL}$. A $100 \mu \mathrm{L}$ volume of each dilution was introduced into wells (in triplicate) in the agar plates already seeded with $100 \mu \mathrm{L}$ of standardized inoculums $\left(10^{6} \mathrm{cfu} / \mathrm{mL}\right)$ of the test microbial strain. All test plates were incubated aerobically at $37^{\circ} \mathrm{C}$ for $24 \mathrm{hrs}$ and observed for the inhibition zones. MIC, taken as the lowest concentration of the chemical compound that completely inhibited the growth of the microbe, showed by a clear zone of inhibition, was recorded for each test organism. Ciprofloxacin was used as positive control.

2.3.4. Antifungal Activity. The antifungal activity of Schiff bases and their metal complexes was evaluated by poison food technique [21]. The molds were grown on Sabouraud's dextrose agar (SDA) at $25^{\circ} \mathrm{C}$ for 7 days and used as inocula. The $15 \mathrm{~mL}$ of molten SDA $\left(45^{\circ} \mathrm{C}\right)$ was poisoned by the addition of $100 \mu \mathrm{L}$ volume of each compound having concentration of $4.0 \mathrm{mg} / \mathrm{mL}$ reconstituted in DMSO, poured 
into a sterile Petri plate, and allowed it to solidify at room temperature. The solidified poisoned agar plates were inoculated at the center with fungal plugs ( $8 \mathrm{~mm}$ diameter) obtained from the colony margins and incubated at $25^{\circ} \mathrm{C}$ for 7 days. DMSO was used as the negative control whereas fluconazole was used as the positive control. The experiments were performed in triplicates. Diameter of fungal colonies was measured and expressed as percent mycelial inhibition.

Percent inhibition of mycelial growth $=(\mathrm{dc}-\mathrm{dt}) / \mathrm{dc} \times$ 100.

dc: average diameter of fungal colony in negative control sets.

dt: average diameter fungal colony in experimental sets.

\section{Results and Discussion}

The Schiff bases (Figure 1) were soluble in ethanol and methanol. All the metal complexes are colored, nonhygroscopic solids stable in air, insoluble in water and many common organic solvents but soluble in DMF and DMSO, decomposed at higher temperature. The elemental analysis supports the formation of $1: 1$ and $1: 2$ metal complexes of $\mathrm{HL}^{1-2}$ with $\mathrm{Co}(\mathrm{II}), \mathrm{Ni}(\mathrm{II}), \mathrm{Cu}(\mathrm{II})$, and $\mathrm{Zn}(\mathrm{II})$ metal ions. The molar conductance values of the complexes (measured in $10^{-3} \mathrm{MDMF}$ ) are in the range $1.5-3.6 \mathrm{ohm}^{-1} \mathrm{~cm}^{2} \mathrm{~mol}^{-1}$ indicating the nonelectrolytic nature [22]. The purity of ligands and their metal complexes has been checked by TLC.

3.1. IR Spectra. The IR spectral data of the Schiff base ligands and their complexes are listed in Table 1. The IR spectra of the complexes have been compared with those of the free ligand in order to determine the coordination sites that may get involved in chelation. By comparing, it was found that azomethine group frequency $v(\mathrm{~N}=\mathrm{CH})$ is present in the free ligands at $1595-1597 \mathrm{~cm}^{-1}$. This band is shifted to the lower frequency $(22-24)$ by $5-15 \mathrm{~cm}^{-1}$ in the spectra of the complexes, indicating coordination of azomethine nitrogen towards the metal ion $(\mathrm{M}-\mathrm{N})$.

A new band at $485-514 \mathrm{~cm}^{-1}$ due to $v(\mathrm{M}-\mathrm{N})$ is further confirmed the coordination of metal to azomethine nitrogen. The Schiff bases exhibit a weak broad band around $2700 \mathrm{~cm}^{-1}$ due to $v(\mathrm{~S}-\mathrm{H})$ vibrations $[23,24]$. This band disappeared in the spectra of the metal complexes indicating deprotonation and complexation through sulphur. In the spectra of metal complexes, bands appeared at $733-771 \mathrm{~cm}^{-1}$ and $334-352 \mathrm{~cm}^{-1}$ were assigned to $\nu(\mathrm{C}-\mathrm{S})$ and $\nu(\mathrm{M}-\mathrm{S})$, respectively $[22,25]$. In the spectra of metal complexes, a broad band in the region $3200-3490 \mathrm{~cm}^{-1}$ indicated the presence of coordinated water molecules. A strong band in the region $1738-1750 \mathrm{~cm}^{-1}$ has been assigned to $v\left(\mathrm{OOCCH}_{3}\right)$ in $1: 1$ metal complexes.

3.2. ${ }^{1} \mathrm{H}$ NMR Spectra. The ${ }^{1} \mathrm{H}$ NMR spectra have been recorded for Schiff bases and $\mathrm{Zn}$ (II) complexes (Table 2). The NMR spectra of metal complexes indicated a shift of electron density from the ligand to metal. The ligands $\left[\mathrm{HL}^{1-2}\right]$ showed characteristic azomethine proton singlet at $\delta$
10.40 and $10.55 \mathrm{ppm}$, respectively. The characteristic signal, due to azomethine proton deshielded in the spectra of metal complexes, suggests coordination of metal ion to azomethine nitrogen atom $[23,25,26]$. In addition to this, the signal at $\delta 11.10-11.09 \mathrm{ppm}$ is ascribed to $\mathrm{SH}$ proton. Disappearance of $\mathrm{SH}$ protons signal in the spectra of metal complexes supported the deprotonation of thiol group and chelation with metal $(\mathrm{M}-\mathrm{S})$. The aromatic protons of Schiff bases appeared as a double of doublet and two doublets at $\delta 7.35$, 7.52 and $8.08 \mathrm{ppm}$, respectively. These aromatic protons signals show a slight downfield shift upon coordination. In the spectra of $1: 1 \mathrm{Zn}$ complexes singlet at $\delta 2.29$ and $2.32 \mathrm{ppm}$ are due to methyl group of acetate ion.

3.3. Magnetic Measurements and Electronic Spectra. The magnetic moment measurements and electronic spectra provided good information regarding the arrangements of the ligands around the metal ions (Table 3 ). The $1: 1$ and $1: 2 \mathrm{Co}(\mathrm{II})$ complexes show magnetic moment $\left(\mu_{\text {eff. }}\right)$ 4.83-4.95 BM, well within the expected range of octahedral complex (4.3-5.2 BM) [24, 27]. Co(II) complexes exhibit two absorption bands in the region $10885-10935 \mathrm{~cm}^{-1}\left(\nu_{1}\right)$ and $20010-20998 \mathrm{~cm}^{-1}\left(\nu_{3}\right)$, which are assigned to ${ }^{4} \mathrm{~T}_{1 \mathrm{~g}}(\mathrm{~F})$ $\rightarrow{ }^{4} \mathrm{~T}_{2 \mathrm{~g}}(\mathrm{~F})\left(\nu_{1}\right) ;{ }^{4} \mathrm{~T}_{1 \mathrm{~g}}(\mathrm{~F}) \rightarrow{ }^{4} \mathrm{~T}_{\mathrm{lg}}(\mathrm{P})\left(\nu_{3}\right)$ transitions [23$25,27]$. These are the characteristic bands of high spin octahedral $\mathrm{Co}$ (II) complexes; $\nu_{2}$ is not observed, but it can be calculated $[28,29]$ by using relation $\nu_{2}=\nu_{1}+10 \mathrm{Dq}$, which is very close to $\left(\nu_{3}\right)$ transition. The ligand field parameters $(\mathrm{Dq}, \mathrm{B}, \beta, \beta \%)$ have also been calculated for $\mathrm{Co}(\mathrm{II})$ complexes by using Band-fitting equation [30]. The crystal field stabilizing energy (Dq) value was found to be $\sim 1200 \mathrm{~cm}^{-1}$. These values are well within the range reported for the octahedral complexes [30]. The Racah parameter (B) is found to be $683-755 \mathrm{~cm}^{-1}\left(<971 \mathrm{~cm}^{-1}\right)$, suggesting an overlapping of ligand metal orbital's. The nephelauxetic ratio $(\beta)$ for the $1: 1$ and $1: 2$ cobalt complexes is less than one suggesting partial covalency in the metal ligand bond.

The nickel complexes show magnetic moment in the range 3.43-3.47 BM, which corresponds to octahedral environment around the central metal ion. Nickel(II) complexes generally show three absorption bands in octahedral environment corresponding to ${ }^{3} \mathrm{~A}_{2 \mathrm{~g}}(\mathrm{~F}) \rightarrow{ }^{3} \mathrm{~T}_{2 \mathrm{~g}}(\mathrm{~F})\left(\nu_{1}\right),{ }^{3} \mathrm{~A}_{2 \mathrm{~g}}(\mathrm{~F})$ $\rightarrow{ }^{3} \mathrm{~T}_{1 \mathrm{~g}}(\mathrm{~F})\left(\nu_{2}\right)$ and ${ }^{3} \mathrm{~A}_{2 \mathrm{~g}}(\mathrm{~F}) \rightarrow 3 \mathrm{~T}_{\mathrm{lg}}(\mathrm{P})\left(\nu_{3}\right)$ transitions [28]. The $1: 1$ and $1: 2 \mathrm{Ni}(\mathrm{II})$ complexes of $\mathrm{HL}^{1-2}$ Schiff bases also show above three transitions in the region $9999-10123 \mathrm{~cm}^{-1}$ $\left(\nu_{1}\right), 16380-17320 \mathrm{~cm}^{-1}\left(\nu_{2}\right)$, and $24885-24993 \mathrm{~cm}^{-1}\left(\nu_{3}\right)$, suggesting distorted octahedral geometry for the complexes. The ligand field parameters ( $\mathrm{Dq}, \mathrm{B}, \beta, \beta \%$ ) have also been calculated for $\mathrm{Ni}(\mathrm{II})$ complexes by using Band-fitting equation [30]. These parameters indicate significant covalent character of the metal ligand bonds.

The $\mathrm{Cu}(\mathrm{II})$ complex has magnetic moment value 1.92$2.11 \mathrm{BM}$, which fall in the normal range (1.7-2.2 BM). The electronic spectra of $\mathrm{Cu}$ (II) complexes showed broad band around $18550 \mathrm{~cm}^{-1}$, which is assigned to ${ }^{2} \mathrm{~B}_{1 \mathrm{~g}} \rightarrow{ }^{2} \mathrm{~A}_{1 \mathrm{~g}}$ $\left(\nu_{1}\right)$ transition. It is a characteristic band of square planar geometry around the $\mathrm{Cu}(\mathrm{II})[31]$. 
TABLE 1: IR spectral data of the ligands and their metal complexes $\left(\mathrm{cm}^{-1}\right)$.

\begin{tabular}{|c|c|c|c|c|c|c|c|}
\hline Compound & $\nu(\mathrm{N}=\mathrm{CH})$ & $\nu(\mathrm{C}-\mathrm{S})$ & $v(\mathrm{~S}-\mathrm{H})$ & $v\left(\mathrm{OOCCH}_{3}\right)$ & $\nu\left(\mathrm{H}_{2} \mathrm{O} / \mathrm{OH}\right)$ & $\nu(\mathrm{M}-\mathrm{S})$ & $v(\mathrm{M}-\mathrm{N})$ \\
\hline $\mathrm{HL}^{1}$ & 1595 & - & 2732 & - & - & - & - \\
\hline $\mathrm{Co}\left(\mathrm{L}^{1}\right)(\mathrm{OAc}) \cdot 3 \mathrm{H}_{2} \mathrm{O}$ & 1585 & 741 & - & 1744 & 3426 & 338 & 498 \\
\hline $\mathrm{Co}\left(\mathrm{L}^{1}\right)_{2} \cdot 2 \mathrm{H}_{2} \mathrm{O}$ & 1585 & 743 & - & - & 3488 & 334 & 494 \\
\hline $\mathrm{Ni}\left(\mathrm{L}^{1}\right)(\mathrm{OAc}) \cdot 3 \mathrm{H}_{2} \mathrm{O}$ & 1587 & 749 & - & 1742 & 3471 & 342 & 510 \\
\hline $\mathrm{Ni}\left(\mathrm{L}^{1}\right)_{2} \cdot 2 \mathrm{H}_{2} \mathrm{O}$ & 1588 & 733 & - & - & 3394 & 339 & 514 \\
\hline $\mathrm{Cu}\left(\mathrm{L}^{1}\right)(\mathrm{OAc}) \cdot \mathrm{H}_{2} \mathrm{O}$ & 1590 & 748 & - & 1744 & 3310 & 345 & 513 \\
\hline $\mathrm{Cu}\left(\mathrm{L}^{1}\right)_{2}$ & 1589 & 750 & - & - & - & 348 & 491 \\
\hline $\mathrm{Zn}\left(\mathrm{L}^{1}\right)(\mathrm{OAc}) \cdot 3 \mathrm{H}_{2} \mathrm{O}$ & 1588 & 745 & - & 1750 & 3441 & 352 & 489 \\
\hline $\mathrm{Zn}\left(\mathrm{L}^{1}\right)_{2} \cdot 2 \mathrm{H}_{2} \mathrm{O}$ & 1585 & 748 & - & - & 3440 & 348 & 492 \\
\hline $\mathrm{HL}^{2}$ & 1597 & - & 2703 & - & - & - & - \\
\hline $\mathrm{Co}\left(\mathrm{L}^{2}\right)(\mathrm{OAc}) \cdot 3 \mathrm{H}_{2} \mathrm{O}$ & 1585 & 733 & - & 1738 & 3294 & 344 & 485 \\
\hline $\mathrm{Co}\left(\mathrm{L}^{2}\right)_{2} \cdot 2 \mathrm{H}_{2} \mathrm{O}$ & 1586 & 741 & - & - & 3310 & 338 & 488 \\
\hline $\mathrm{Ni}\left(\mathrm{L}^{2}\right)(\mathrm{OAc}) \cdot 3 \mathrm{H}_{2} \mathrm{O}$ & 1585 & 771 & - & 1744 & 3280 & 338 & 489 \\
\hline $\mathrm{Ni}\left(\mathrm{L}^{2}\right)_{2} \cdot 2 \mathrm{H}_{2} \mathrm{O}$ & 1587 & 755 & - & - & 3287 & 335 & 492 \\
\hline $\mathrm{Cu}\left(\mathrm{L}^{2}\right)(\mathrm{OAc}) \cdot \mathrm{H}_{2} \mathrm{O}$ & 1585 & 733 & - & 1746 & 3400 & 343 & 503 \\
\hline $\mathrm{Cu}\left(\mathrm{L}^{2}\right)_{2}$ & 1586 & 733 & - & - & - & 348 & 503 \\
\hline $\mathrm{Zn}\left(\mathrm{L}^{2}\right)(\mathrm{OAc}) \cdot 3 \mathrm{H}_{2} \mathrm{O}$ & 1589 & 748 & - & 1740 & 3318 & 347 & 500 \\
\hline $\mathrm{Zn}\left(\mathrm{L}^{2}\right)_{2} \cdot 2 \mathrm{H}_{2} \mathrm{O}$ & 1589 & 771 & - & - & 3310 & 349 & 497 \\
\hline
\end{tabular}

TABLE 2: ${ }^{1} \mathrm{H}$ NMR spectral data of Schiff bases and their metal complexes.

\begin{tabular}{|c|c|}
\hline Compounds & ${ }^{1} \mathrm{H} \mathrm{NMR}\left(\mathrm{CDCl}_{3} / \mathrm{DMSO}-\mathrm{d}_{6}\right)(\mathrm{ppm})$ \\
\hline $\mathrm{HL}^{1}\left[\mathrm{C}_{10} \mathrm{H}_{8} \mathrm{Cl}_{2} \mathrm{~N}_{4} \mathrm{~S}\right]$ & $\begin{array}{l}2.49\left(\mathrm{~s}, 3 \mathrm{H},-\mathrm{CH}_{3}\right), 7.35(\mathrm{dd}, 1 \mathrm{H}, \mathrm{Ar}-\mathrm{H}), 7.52(\mathrm{~d}, 1 \mathrm{H}, \mathrm{Ar} \mathrm{H}), 8.08(\mathrm{~d}, 1 \mathrm{H}, \mathrm{ArH}), 10.40(\mathrm{~s}, 1 \mathrm{H},-\mathrm{N}=\mathrm{CH}-) \text {, } \\
11.10(\mathrm{~s}, 1 \mathrm{H},-\mathrm{SH})\end{array}$ \\
\hline $\begin{array}{l}\mathrm{Zn}\left(\mathrm{L}^{1}\right) \mathrm{OAc} \cdot 3 \mathrm{H}_{2} \mathrm{O} \\
{\left[\mathrm{C}_{12} \mathrm{H}_{16} \mathrm{Cl}_{2} \mathrm{~N}_{4} \mathrm{O}_{5} \mathrm{SZn}\right]}\end{array}$ & $\begin{array}{l}2.37\left(\mathrm{~s}, 3 \mathrm{H},-\mathrm{CH}_{3}\right), 7.41(\mathrm{dd}, 1 \mathrm{H}, \mathrm{Ar}-\mathrm{H}), 7.79(\mathrm{~d}, 1 \mathrm{H}, \mathrm{Ar}-\mathrm{H}), 8.12(\mathrm{~d}, 1 \mathrm{H}, \mathrm{Ar}-\mathrm{H}), 10.52(\mathrm{~s}, 1 \mathrm{H},-\mathrm{N}=\mathrm{CH}-) \text {, } \\
2.29\left(\mathrm{~s}, 3 \mathrm{H}, \mathrm{CH}_{3} \mathrm{COO}\right)\end{array}$ \\
\hline $\begin{array}{l}\mathrm{Zn}\left(\mathrm{L}^{1}\right)_{2} \cdot 2 \mathrm{H}_{2} \mathrm{O} \\
{\left[\mathrm{C}_{20} \mathrm{H}_{18} \mathrm{Cl}_{4} \mathrm{~N}_{8} \mathrm{O}_{2} \mathrm{~S}_{2} \mathrm{Zn}\right]}\end{array}$ & $2.58\left(\mathrm{~s}, 3 \mathrm{H},-\mathrm{CH}_{3}\right), 7.47(\mathrm{dd}, 1 \mathrm{H}, \mathrm{Ar}-\mathrm{H}), 7.78(\mathrm{~d}, 1 \mathrm{H}, \mathrm{Ar}-\mathrm{H}), 8.08(\mathrm{~d}, 1 \mathrm{H}, \mathrm{Ar}-\mathrm{H}), 10.58(\mathrm{~s}, 1 \mathrm{H},-\mathrm{N}=\mathrm{CH}-)$ \\
\hline $\mathrm{HL}^{2}\left[\mathrm{C}_{11} \mathrm{H}_{10} \mathrm{Cl}_{2} \mathrm{~N}_{4} \mathrm{~S}\right]$ & $\begin{array}{l}2.84\left(\mathrm{q}, 2 \mathrm{H},-\mathrm{CH}_{2} \mathrm{CH}_{3}\right), 1.35\left(\mathrm{t}, 3 \mathrm{H},-\mathrm{CH}_{2} \mathrm{CH}_{3}\right), 7.35(\mathrm{dd}, 1 \mathrm{H}, \mathrm{Ar}-\mathrm{H}), 7.52(\mathrm{~d}, 1 \mathrm{H}, \mathrm{Ar}-\mathrm{H}), 8.07(\mathrm{~d}, 1 \mathrm{H}, \\
\operatorname{Ar}-\mathrm{H}), 10.55(\mathrm{~s}, 1 \mathrm{H},-\mathrm{N}=\mathrm{CH}-), 11.09(\mathrm{~s}, 1 \mathrm{H},-\mathrm{SH})\end{array}$ \\
\hline $\begin{array}{l}\mathrm{Zn}\left(\mathrm{L}^{2}\right) \mathrm{OAc} \cdot 3 \mathrm{H}_{2} \mathrm{O} \\
{\left[\mathrm{C}_{13} \mathrm{H}_{18} \mathrm{Cl}_{2} \mathrm{~N}_{4} \mathrm{O}_{5} \mathrm{SZn}\right]}\end{array}$ & $\begin{array}{l}2.67\left(\mathrm{q}, 2 \mathrm{H},-\mathrm{CH}_{2} \mathrm{CH}_{3}\right), 1.22\left(\mathrm{t}, 3 \mathrm{H},-\mathrm{CH}_{2} \underline{\mathrm{CH}}_{3}\right), 7.43(\mathrm{dd}, 1 \mathrm{H}, \mathrm{Ar}-\mathrm{H}), 7.82(\mathrm{~d}, 1 \mathrm{H}, \mathrm{Ar}-\mathrm{H}), 8.13(\mathrm{~d}, 1 \mathrm{H}, \mathrm{Ar} \\
\mathrm{H}), 10.61(\mathrm{~s}, 1 \mathrm{H},-\mathrm{N}=\mathrm{CH}-), 2.32\left(\mathrm{~s}, 3 \mathrm{H}, \underline{\mathrm{C}}_{3} \mathrm{COO}\right)\end{array}$ \\
\hline $\begin{array}{l}\mathrm{Zn}\left(\mathrm{L}^{2}\right)_{2} \cdot 2 \mathrm{H}_{2} \mathrm{O} \\
{\left[\mathrm{C}_{22} \mathrm{H}_{22} \mathrm{Cl}_{4} \mathrm{~N}_{8} \mathrm{O}_{2} \mathrm{~S}_{2} \mathrm{Zn}\right]}\end{array}$ & $\begin{array}{l}2.66\left(\mathrm{q}, 2 \mathrm{H},-\mathrm{CH}_{2} \mathrm{CH}_{3}\right), 1.18\left(\mathrm{t}, 3 \mathrm{H},-\mathrm{CH}_{2} \mathrm{CH}_{3}\right), 7.55(\mathrm{dd}, 1 \mathrm{H}, \mathrm{Ar}-\mathrm{H}), 7.83(\mathrm{~d}, 1 \mathrm{H}, \mathrm{Ar}-\mathrm{H}), 8.13(\mathrm{~d}, 1 \mathrm{H}, \mathrm{Ar} \\
\mathrm{H}), 10.60(\mathrm{~s}, 1 \mathrm{H},-\mathrm{N}=\mathrm{CH}-)\end{array}$ \\
\hline
\end{tabular}

TABLE 3: Electronic spectral data of metal complexes.

\begin{tabular}{|c|c|c|c|c|c|c|c|c|}
\hline \multirow{2}{*}{ Compound } & \multicolumn{3}{|c|}{ Transitions $\left(\mathrm{cm}^{-1}\right)$} & \multirow{2}{*}{$\mathrm{Dq} \mathrm{cm}^{-1}$} & \multirow{2}{*}{$\mathrm{B} \mathrm{cm}^{-1}$} & \multirow{2}{*}{$v_{2} / \nu_{1}$} & \multirow{2}{*}{$\beta$} & \multirow{2}{*}{$\beta \%$} \\
\hline & $v_{1}$ & $\nu_{2}$ & $\nu_{3}$ & & & & & \\
\hline $\mathrm{Co}\left(\mathrm{L}^{1}\right)(\mathrm{OAc}) \cdot 3 \mathrm{H}_{2} \mathrm{O}$ & 10897 & $23031^{*}$ & 20998 & 1213.4 & 755.9 & 2.11 & 0.778 & 22.2 \\
\hline $\mathrm{Co}\left(\mathrm{L}^{1}\right)_{2} \cdot 2 \mathrm{H}_{2} \mathrm{O}$ & 10885 & $22884^{*}$ & 20993 & 1199.9 & 748.1 & 2.10 & 0.770 & 23.0 \\
\hline $\mathrm{Ni}\left(\mathrm{L}^{1}\right)(\mathrm{OAc}) \cdot 3 \mathrm{H}_{2} \mathrm{O}$ & 10117 & 17201 & 24932 & 1011.7 & 785.4 & 1.70 & 0.754 & 24.5 \\
\hline $\mathrm{Ni}\left(\mathrm{L}^{1}\right)_{2} \cdot 2 \mathrm{H}_{2} \mathrm{O}$ & 10123 & 17320 & 24950 & 1012.3 & 793.4 & 1.71 & 0.762 & 23.7 \\
\hline $\mathrm{Co}\left(\mathrm{L}^{2}\right)(\mathrm{OAc}) \cdot 3 \mathrm{H}_{2} \mathrm{O}$ & 10923 & $23017^{*}$ & 20010 & 1209.4 & 683.9 & 2.09 & 0.704 & 29.6 \\
\hline $\mathrm{Co}\left(\mathrm{L}^{2}\right)_{2} \cdot 2 \mathrm{H}_{2} \mathrm{O}$ & 10935 & $23041^{*}$ & 20016 & 1210.6 & 683.5 & 2.10 & 0.703 & 29.6 \\
\hline $\mathrm{Ni}\left(\mathrm{L}^{2}\right)(\mathrm{OAc}) \cdot 3 \mathrm{H}_{2} \mathrm{O}$ & 9999 & 16380 & 24885 & 999.9 & 751.2 & 1.63 & 0.721 & 27.9 \\
\hline $\mathrm{Ni}\left(\mathrm{L}^{2}\right)_{2} \cdot 2 \mathrm{H}_{2} \mathrm{O}$ & 9957 & 16397 & 24889 & 995.7 & 761.0 & 1.64 & 0.731 & 26.9 \\
\hline
\end{tabular}

* Calculated value. 
TABLE 4: Thermoanalytical results (TG) of the metal complexes.

\begin{tabular}{|c|c|c|c|c|c|}
\hline \multirow{2}{*}{ Compound } & \multirow{2}{*}{ Steps } & \multirow{2}{*}{ Temp. $\left({ }^{\circ} \mathrm{C}\right)$} & \multicolumn{2}{|c|}{ TG mass $\%$} & \multirow[t]{2}{*}{ Assignments } \\
\hline & & & Calcd. & Found & \\
\hline $\mathrm{Cu}\left(\mathrm{L}^{2}\right)_{2}$ & $\begin{array}{l}1 \text { st } \\
2 \text { nd } \\
3 r d\end{array}$ & $\begin{array}{l}80-305 \\
305-505 \\
505-695\end{array}$ & $\begin{array}{l}47.90 \\
21.26 \\
21.26 \\
11.98\end{array}$ & $\begin{array}{l}45.29 \\
20.27 \\
20.05 \\
15.16\end{array}$ & $\begin{array}{c}-\mathrm{C}_{14} \mathrm{H}_{8} \mathrm{Cl}_{4} \text { (organic moiety) } \\
-\mathrm{C}_{4} \mathrm{H}_{5} \mathrm{~N}_{4} \mathrm{~S} \text { (triazole ring) } \\
-\mathrm{C}_{4} \mathrm{H}_{5} \mathrm{~N}_{4} \mathrm{~S} \text { (triazole ring) } \\
-\mathrm{CuO} \text { (residue) }\end{array}$ \\
\hline $\mathrm{Zn}\left(\mathrm{L}^{1}\right)_{2} \cdot 2 \mathrm{H}_{2} \mathrm{O}$ & $\begin{array}{l}1 \text { st } \\
2 \text { nd } \\
3 r d\end{array}$ & $\begin{array}{l}80-230 \\
230-560 \\
560-700\end{array}$ & $\begin{array}{c}5.37 \\
51.30 \\
33.73 \\
11.90\end{array}$ & $\begin{array}{c}4.98 \\
51.50 \\
31.12 \\
12.40\end{array}$ & $\begin{array}{c}-\mathrm{H}_{4} \mathrm{O}_{2} \text { (two water molecule) } \\
-\mathrm{C}_{14} \mathrm{H}_{8} \mathrm{Cl}_{4} \mathrm{~N}_{2} \text { (organic moiety) } \\
-\mathrm{C}_{6} \mathrm{H}_{6} \mathrm{~N}_{6} \mathrm{~S}_{2} \text { (triazole ring) } \\
-\mathrm{ZnO} \text { (residue) }\end{array}$ \\
\hline
\end{tabular}

3.4. Thermal Studies. Thermogravimetric analysis was carried out for $\mathrm{Cu}\left(\mathrm{L}^{2}\right)_{2}$ and $\mathrm{Zn}\left(\mathrm{L}^{1}\right)_{2} \cdot 2 \mathrm{H}_{2} \mathrm{O}$ (Figure 2) from $80^{\circ} \mathrm{C}$ to $700^{\circ} \mathrm{C}$ in atmospheric air $[22,23,25]$. The decomposition temperature, pyrolysed products, percentage mass loss of the complexes, and the ash (percent) are given in Table 4. The thermograms for both of these complexes show three decomposition steps. In case of $\mathrm{Cu}\left(\mathrm{L}^{2}\right)_{2}$ complex, the first step $50-305^{\circ} \mathrm{C}$ results in a mass loss of $45.29 \%$ (calcd. $47.90 \%$ ) corresponding to a loss organic moiety. The 2 nd and 3rd steps $\left(305-695^{\circ} \mathrm{C}\right)$ correspond to removal of two triazole molecules with mass loss of $40.32 \%$ (calcd. $42.52 \%$ ) of the ligand leaving metal oxide as residue.

In case of $\mathrm{Zn}\left(\mathrm{L}^{1}\right)_{2} \cdot 2 \mathrm{H}_{2} \mathrm{O}$ complex, the first step 50 $230^{\circ} \mathrm{C}$ results in a mass loss of $4.98 \%$ (calcd. $5.37 \%$ ) corresponding to loss of two water molecules. The 2 nd steps corresponds to loss of organic moiety with mass loss $51.50 \%$ (calcd. $51.30 \%$ ) in the temperature range $230-560^{\circ} \mathrm{C}$. The 3rd step $\left(560-700^{\circ} \mathrm{C}\right)$ corresponds to removal of two triazole molecules with mass loss of $31.12 \%$ (calcd. $33.73 \%$ ). The decomposition of both of the complexes ended with oxide formation.

3.5. ESR Spectra. ESR spectra of $1: 1$ and $1: 2$ copper(II) complexes in solid state at $298 \mathrm{~K}$ show an intense broad signal having no hyperfine structure. The observed $g$ values for $\mathrm{Cu}\left(\mathrm{L}^{1}\right)(\mathrm{OAc}) \cdot \mathrm{H}_{2} \mathrm{O}$ at room temperature are $g_{\|}=2.18$, $g_{\perp}=2.10, g_{\mathrm{av}}=2.12, G=1.81$ and for $\mathrm{Cu}\left(\mathrm{L}^{1}\right)_{2}$ at room temperature are $g_{\|}=2.19, g_{\perp}=2.12, g_{\text {av }}=2.14, G=1.59$. The trend in $g$ values $\left(g_{\|}>g_{\perp}>2.00\right)$ suggested that the unpaired electron is localized in the $d x^{2}-y^{2}$ orbital and corresponds to square planar geometry of the complexes. The $g_{\|}<2.3$ value confirms the covalent character of the metal ligand bond. The axial symmetry parameter $G$ is less than 4.0 , indicates considerable exchange interaction in the solid complex [32].

3.6. Antimicrobial Discussion. The Schiff bases and their metal complexes were screened for their antibacterial and antifungal activity. All the tested chemical compounds possessed variable antibacterial activity against Staphylococcus aureus, Bacillus subtilis and antifungal activity against Aspergillus niger and Aspergillus flavus. However the compounds in this series were not effective against any Gram-negative bacteria (E. coli and $P$. aeruginosa). Positive controls produced significantly sized inhibition zones against the tested bacteria and fungi; however, negative control produced no observable

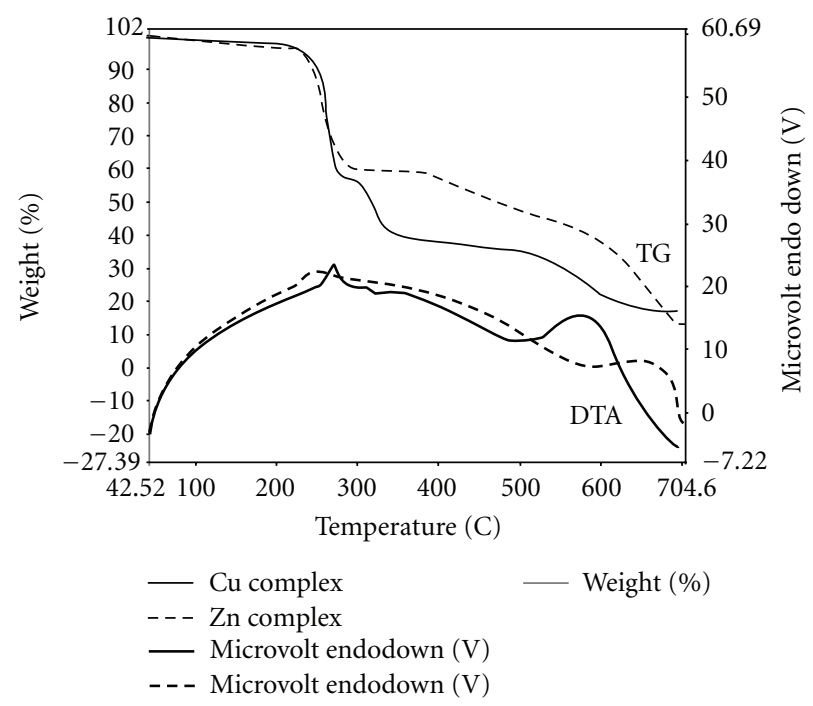

Figure 2: Thermal analyses curve of $\mathrm{Zn}\left(\mathrm{L}^{1}\right)_{2} \cdot 2 \mathrm{H}_{2} \mathrm{O}$ and $\mathrm{Cu}\left(\mathrm{L}^{2}\right)_{2}$.

inhibitory effect against any of the test organism as shown in Tables 5, 6, and 7 .

The tested chemical compounds showed zone of inhibition ranging between 15 and $26 \mathrm{~mm}$ against the Gram positive bacteria. On the basis of zone of inhibition produced against the test bacterium, $\mathrm{Co}\left(\mathrm{L}^{1}\right)(\mathrm{OAc}) \cdot 3 \mathrm{H}_{2} \mathrm{O}$ and $\mathrm{Zn}\left(\mathrm{L}^{1}\right)(\mathrm{OAc}) \cdot 3 \mathrm{H}_{2} \mathrm{O}$ were found to be most effective against $S$. aureus with zone of inhibition ranging between $23.6 \mathrm{~mm}$ and $20.6 \mathrm{~mm}$, respectively, and four compounds $\mathrm{HL}^{1}, \mathrm{Co}\left(\mathrm{L}^{1}\right)(\mathrm{OAc}) \cdot 3 \mathrm{H}_{2} \mathrm{O}, \mathrm{Zn}\left(\mathrm{L}^{1}\right)(\mathrm{OAc}) \cdot 3 \mathrm{H}_{2} \mathrm{O}$ and $\mathrm{Zn}\left(\mathrm{L}^{2}\right)(\mathrm{OAc}) \cdot 3 \mathrm{H}_{2} \mathrm{O}$ were found to be best against B. subtilis, with zone of inhibition ranging between $21.6 \mathrm{~mm}$ and $23.6 \mathrm{~mm}$ (Table 5). In the whole series, the MIC of chemical compounds (Figure 3) ranged between 16 and $256 \mu \mathrm{g} / \mathrm{mL}$ against Gram positive bacteria. Compound $\mathrm{Co}\left(\mathrm{L}^{1}\right)(\mathrm{OAc}) \cdot 3 \mathrm{H}_{2} \mathrm{O}, \mathrm{Zn}\left(\mathrm{L}^{1}\right)(\mathrm{OAc}) \cdot 3 \mathrm{H}_{2} \mathrm{O}$ and $\mathrm{Zn}\left(\mathrm{L}^{2}\right)(\mathrm{OAc}) \cdot 3 \mathrm{H}_{2} \mathrm{O}$ were found to be best, as they exhibit the lowest MIC of $32 \mu \mathrm{g} / \mathrm{mL}$ against $S$. aureus and $16 \mu \mathrm{g} / \mathrm{mL}$ against B. subtilis (Table 6).

All the synthesized compounds screened for their antifungal activity, among these three compounds $\mathrm{HL}^{1}$, $\mathrm{Co}\left(\mathrm{L}^{1}\right)(\mathrm{OAc}) \cdot 3 \mathrm{H}_{2} \mathrm{O}$, and $\mathrm{Co}\left(\mathrm{L}^{1}\right)_{2} \cdot 2 \mathrm{H}_{2} \mathrm{O}$ showed more than $55 \%$ inhibition of mycelial growth against Aspergillus niger, whereas three compounds $\mathrm{HL}^{1}, \mathrm{Co}\left(\mathrm{L}^{1}\right)(\mathrm{OAc}) \cdot 3 \mathrm{H}_{2} \mathrm{O}$, and 
TABLe 5: Antibacterial activity of synthesized compounds.

\begin{tabular}{lcc}
\hline Compound & $\begin{array}{c}\text { Diameter of growth of inhibition zone } \\
(\mathrm{mm})^{\mathrm{a}}\end{array}$ \\
& $\begin{array}{c}\text { Staphylococcus aureus } \\
\text { Bacillus subtilis }\end{array}$ \\
\hline $\mathrm{HL}^{1}$ & 19.0 & 21.3 \\
$\mathrm{Co}\left(\mathrm{L}^{1}\right)(\mathrm{OAc}) \cdot 3 \mathrm{H}_{2} \mathrm{O}$ & 23.6 & 25.6 \\
$\mathrm{Co}\left(\mathrm{L}^{1}\right)_{2} \cdot 2 \mathrm{H}_{2} \mathrm{O}$ & 16.6 & 19.6 \\
$\mathrm{Ni}\left(\mathrm{L}^{1}\right)(\mathrm{OAc}) \cdot 3 \mathrm{H}_{2} \mathrm{O}$ & 16.3 & 18.3 \\
$\mathrm{Ni}\left(\mathrm{L}^{1}\right)_{2} \cdot 2 \mathrm{H}_{2} \mathrm{O}$ & 14.6 & 19.6 \\
$\mathrm{Cu}\left(\mathrm{L}^{1}\right)(\mathrm{OAc}) \cdot \mathrm{H}_{2} \mathrm{O}$ & 20.3 & 18.3 \\
$\mathrm{Cu}\left(\mathrm{L}^{1}\right)_{2}$ & 15.6 & 17.0 \\
$\mathrm{Zn}\left(\mathrm{L}^{1}\right)(\mathrm{OAc}) \cdot 3 \mathrm{H}_{2} \mathrm{O}$ & 20.6 & 23.6 \\
$\mathrm{Zn}\left(\mathrm{L}^{1}\right)_{2} \cdot 2 \mathrm{H}_{2} \mathrm{O}$ & 19.3 & 20.6 \\
$\mathrm{HL}$ & 17.3 & 18.3 \\
$\mathrm{Co}\left(\mathrm{L}^{2}\right)(\mathrm{OAc}) \cdot 3 \mathrm{H}_{2} \mathrm{O}$ & 16.6 & 19.3 \\
$\mathrm{Co}\left(\mathrm{L}^{2}\right)_{2} \cdot 2 \mathrm{H}_{2} \mathrm{O}$ & 17.6 & 20.6 \\
$\mathrm{Ni}\left(\mathrm{L}^{2}\right)(\mathrm{OAc}) \cdot 3 \mathrm{H}_{2} \mathrm{O}$ & 15.6 & 18.3 \\
$\mathrm{Ni}\left(\mathrm{L}^{2}\right)_{2} \cdot 2 \mathrm{H}_{2} \mathrm{O}$ & 15.0 & 16.6 \\
$\mathrm{Cu}\left(\mathrm{L}^{2}\right)(\mathrm{OAc}) \cdot \mathrm{H}_{2} \mathrm{O}$ & 16.3 & 18.5 \\
$\mathrm{Cu}\left(\mathrm{L}^{2}\right)_{2}$ & 19.6 & 21.2 \\
$\mathrm{Zn}\left(\mathrm{L}^{2}\right)(\mathrm{OAc}) \cdot 3 \mathrm{H}_{2} \mathrm{O}$ & 20.3 & 21.6 \\
$\mathrm{Zn}\left(\mathrm{L}^{2}\right)_{2} \cdot 2 \mathrm{H}_{2} \mathrm{O}$ & 18.3 & 19.6 \\
$\mathrm{Ciprofloxacin}$ & 26.6 & 24.0 \\
\hline
\end{tabular}

${ }^{a}$ Values, including diameter of the well $(8 \mathrm{~mm})$, are means of three replicates.

TABle 6: Minimum inhibitory concentration (MIC) (in $\mu \mathrm{g} / \mathrm{mL}$ ) of compounds.

\begin{tabular}{lccc}
\hline Sr. & Compound & Staphylococcus aureus & Bacillus subtilis \\
No. & $\mathrm{HL}^{1}$ & 64 & 32 \\
\hline 1 & $\mathrm{Co}\left(\mathrm{L}^{1}\right)(\mathrm{OAc}) \cdot 3 \mathrm{H}_{2} \mathrm{O}$ & 32 & 16 \\
2 & $\mathrm{Co}\left(\mathrm{L}^{1}\right)_{2} \cdot 2 \mathrm{H}_{2} \mathrm{O}$ & 64 & 64 \\
3 & $\mathrm{Ni}\left(\mathrm{L}^{1}\right)(\mathrm{OAc}) \cdot 3 \mathrm{H}_{2} \mathrm{O}$ & 128 & 64 \\
4 & $\mathrm{Ni}\left(\mathrm{L}^{1}\right)_{2} \cdot 2 \mathrm{H}_{2} \mathrm{O}$ & 128 & 256 \\
5 & $\mathrm{Cu}\left(\mathrm{L}^{1}\right)(\mathrm{OAc}) \cdot \mathrm{H}_{2} \mathrm{O}$ & 64 & 128 \\
6 & $\mathrm{Cu}\left(\mathrm{L}^{1}\right)_{2}$ & 128 & 64 \\
7 & $\mathrm{Zn}\left(\mathrm{L}^{1}\right)(\mathrm{OAc}) \cdot 3 \mathrm{H}_{2} \mathrm{O}$ & 32 & 16 \\
8 & $\mathrm{Zn}\left(\mathrm{L}^{1}\right)_{2} \cdot 2 \mathrm{H}_{2} \mathrm{O}$ & 128 & 32 \\
9 & $\mathrm{HL}$ & 128 & 32 \\
10 & $\mathrm{Co}\left(\mathrm{L}^{2}\right)(\mathrm{OAc}) \cdot 3 \mathrm{H}_{2} \mathrm{O}$ & 64 & 128 \\
11 & $\mathrm{Co}\left(\mathrm{L}^{2}\right)_{2} \cdot 2 \mathrm{H}_{2} \mathrm{O}$ & 128 & 32 \\
12 & $\mathrm{Ni}\left(\mathrm{L}^{2}\right)(\mathrm{OAc}) \cdot 3 \mathrm{H}_{2} \mathrm{O}$ & 256 & 128 \\
13 & $\mathrm{Ni}\left(\mathrm{L}^{2}\right)_{2} \cdot 2 \mathrm{H}_{2} \mathrm{O}$ & 128 & 64 \\
14 & $\mathrm{Cu}\left(\mathrm{L}^{2}\right)(\mathrm{OAc}) \cdot \mathrm{H}_{2} \mathrm{O}$ & 256 & 128 \\
15 & $\mathrm{Cu}\left(\mathrm{L}^{2}\right)_{2}$ & 128 & 32 \\
16 & $\mathrm{Zn}\left(\mathrm{L}^{2}\right)(\mathrm{OAc}) \cdot 3 \mathrm{H}_{2} \mathrm{O}$ & 32 & 16 \\
17 & $\mathrm{Zn}\left(\mathrm{L}^{2}\right)_{2} \cdot 2 \mathrm{H}_{2} \mathrm{O}$ & 64 & 32 \\
18 & $\mathrm{Ciprofloxacin}$ & 5 & 5 \\
19 & & & \\
\hline
\end{tabular}

TABLE 7: Antifungal activity of synthesized compounds.

\begin{tabular}{lcc}
\hline Compound & \multicolumn{2}{c}{ Mycelial growth inhibition $(\%)$} \\
Aspergillus niger & Aspergillus flavus \\
\hline $\mathrm{HL}^{1}$ & 57.7 & 58.8 \\
$\mathrm{Co}\left(\mathrm{L}^{1}\right)(\mathrm{OAc}) \cdot 3 \mathrm{H}_{2} \mathrm{O}$ & 58.8 & 61.1 \\
$\mathrm{Co}\left(\mathrm{L}^{1}\right)_{2} \cdot 2 \mathrm{H}_{2} \mathrm{O}$ & 56.6 & 55.5 \\
$\mathrm{Ni}\left(\mathrm{L}^{1}\right)(\mathrm{OAc}) \cdot 3 \mathrm{H}_{2} \mathrm{O}$ & 53.3 & 55.5 \\
$\mathrm{Ni}\left(\mathrm{L}^{1}\right)_{2} \cdot 2 \mathrm{H}_{2} \mathrm{O}$ & 51.1 & 47.7 \\
$\mathrm{Cu}\left(\mathrm{L}^{1}\right)(\mathrm{OAc}) \cdot \mathrm{H}_{2} \mathrm{O}$ & 50.0 & 48.8 \\
$\mathrm{Cu}\left(\mathrm{L}^{1}\right)_{2}$ & 53.3 & 52.5 \\
$\mathrm{Zn}\left(\mathrm{L}^{1}\right)(\mathrm{OAc}) \cdot 3 \mathrm{H}_{2} \mathrm{O}$ & 54.4 & 56.6 \\
$\mathrm{Zn}\left(\mathrm{L}^{1}\right)_{2} \cdot 2 \mathrm{H}_{2} \mathrm{O}$ & 51.1 & 50.0 \\
$\mathrm{HL}$ & 48.8 & 45.5 \\
$\mathrm{Co}\left(\mathrm{L}^{2}\right)(\mathrm{OAc}) \cdot 3 \mathrm{H}_{2} \mathrm{O}$ & 46.6 & 47.7 \\
$\mathrm{Co}\left(\mathrm{L}^{2}\right)_{2} \cdot 2 \mathrm{H}_{2} \mathrm{O}$ & 48.8 & 50.0 \\
$\mathrm{Ni}\left(\mathrm{L}^{2}\right)(\mathrm{OAc}) \cdot 3 \mathrm{H}_{2} \mathrm{O}$ & 44.4 & 45.5 \\
$\mathrm{Ni}\left(\mathrm{L}^{2}\right)_{2} \cdot 2 \mathrm{H}_{2} \mathrm{O}$ & 45.5 & 43.3 \\
$\mathrm{Cu}\left(\mathrm{L}^{2}\right)(\mathrm{OAc}) \cdot \mathrm{H}_{2} \mathrm{O}$ & 48.8 & 50.0 \\
$\mathrm{Cu}\left(\mathrm{L}^{2}\right)_{2}$ & 52.5 & 54.4 \\
$\mathrm{Zn}\left(\mathrm{L}^{2}\right)(\mathrm{OAc}) \cdot 3 \mathrm{H}_{2} \mathrm{O}$ & 53.3 & 52.5 \\
$\mathrm{Zn}\left(\mathrm{L}^{2}\right)_{2} \cdot 2 \mathrm{H}_{2} \mathrm{O}$ & 50.0 & 51.1 \\
$\mathrm{Fluconazole}$ & 81.1 & 77.7 \\
\hline
\end{tabular}

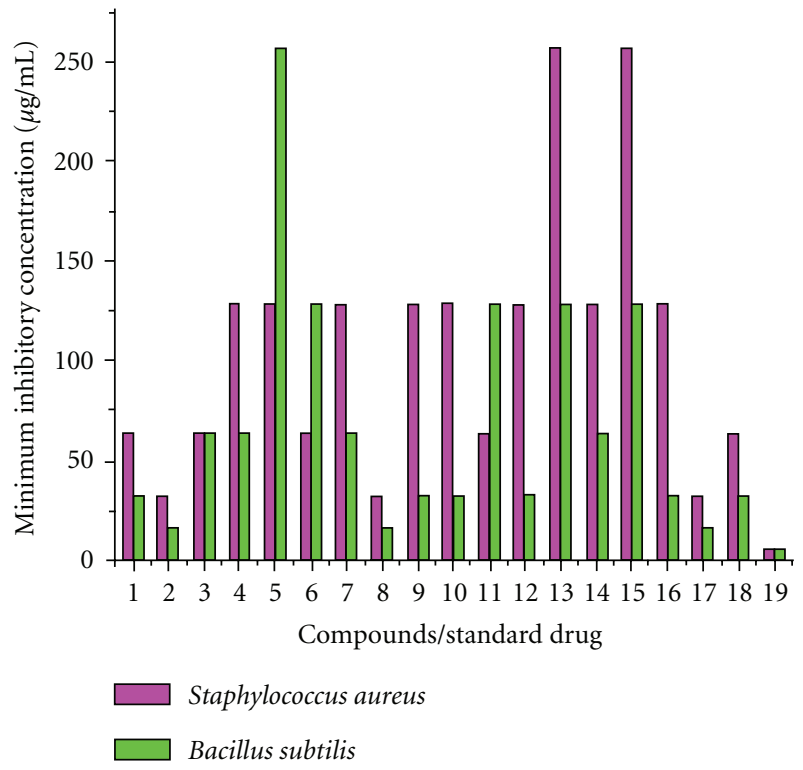

Figure 3: Comparison of minimum inhibitory concentration of compounds with Ciprofloxacin.

$\mathrm{Zn}\left(\mathrm{L}^{1}\right)(\mathrm{OAc}) \cdot 3 \mathrm{H}_{2} \mathrm{O}$, showed more than $55 \%$ inhibition of mycelial growth against A. flavus. $\mathrm{Co}\left(\mathrm{L}^{1}\right)(\mathrm{OAc}) \cdot 3 \mathrm{H}_{2} \mathrm{O}$ showed the highest inhibition of fungal mycelium $(61 \%)$ against $A$. flavus (Table 7). Among all the tested chemical compounds, $\mathrm{Co}\left(\mathrm{L}^{1}\right)(\mathrm{OAc}) \cdot 3 \mathrm{H}_{2} \mathrm{O}$ showed highest antibacterial and antifungal activity. The antimicrobial studies suggested that the Schiff bases were found to be biologically active and their metal complexes showed significantly 

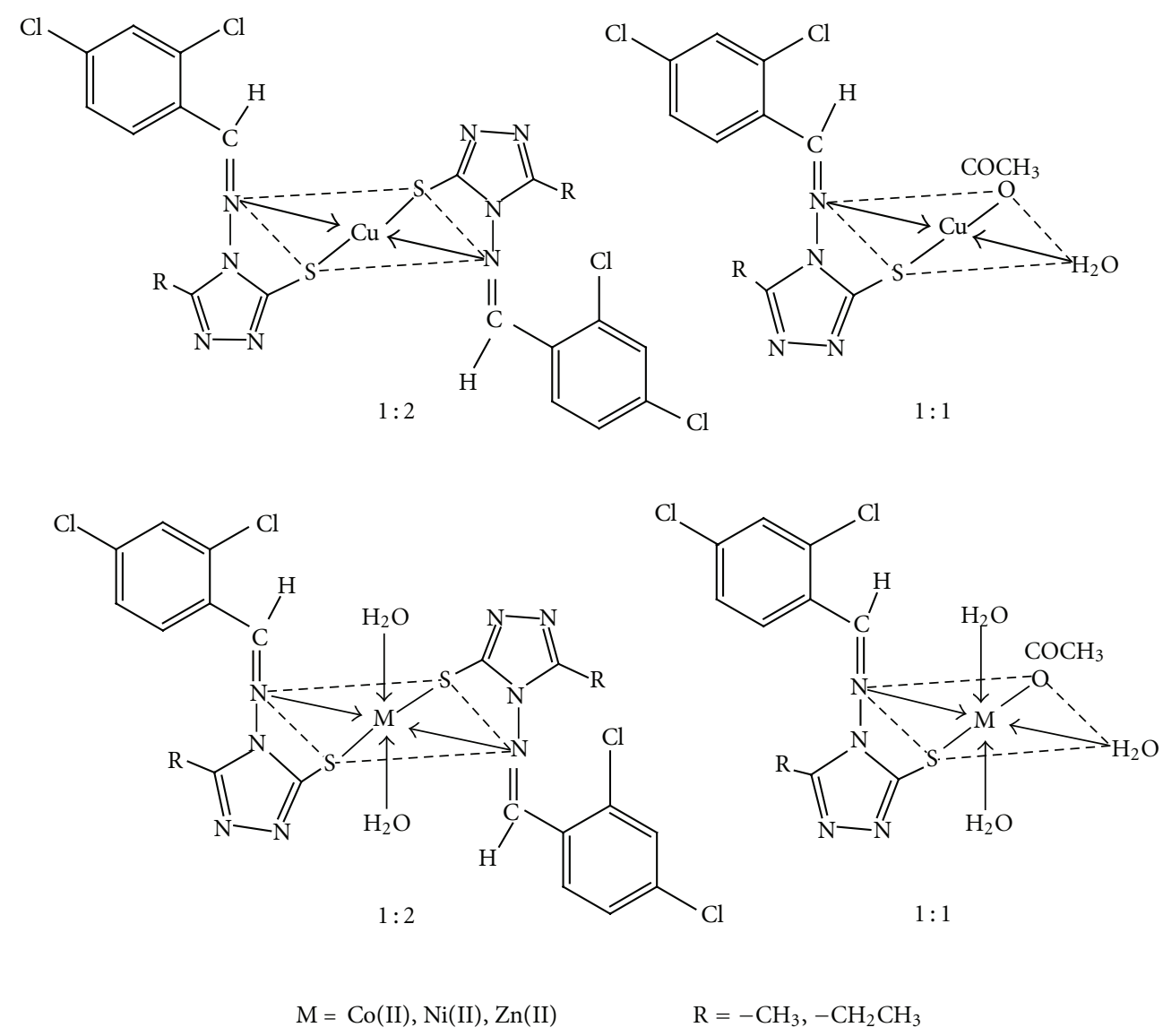

FIGURE 4: Structures of metal complexes.

enhanced antibacterial and antifungal activity against microbial strains in comparison to the free ligands. The overtone's concept [33] and Tweedy's chelation theory [34] can be used to explain the enhanced in antimicrobial activity of the metal complexes. According to the Overtone's concept of cell permeability, the lipid membrane surrounding the cell favors the passage of only lipid-soluble materials; therefore, liposolubility is an important factor which controls the antimicrobial activity. On chelation, polarity of the metal ion is reduced to a greater extent due the overlapping of the ligand orbital and partial sharing of the positive charge of the metal ion with donor groups. Moreover, delocalization of the $\pi$-electrons over the whole chelate ring is increased and lipophilicity of the complexes is enhanced. The increased lipophilicity enhances the penetration of the complexes into the lipid membranes and blocks the metal binding sites in the enzymes of microorganisms. These complexes also disturb the respiration process of the cell and thus block the synthesis of proteins, which restricts further growth of the organism. In general, metal complexes are more active than ligands as they may serve as principal cytotoxic species.

\section{Conclusion}

The Schiff bases $\mathrm{HL}^{1}$ and $\mathrm{HL}^{2}$ coordinate in $1: 1$ and $1: 2$ metal-ligand ratios, as confirmed by analytical, IR, PMR, electronic, magnetic measurements, and thermal studies. The presence of coordinated water in metal complexes was confirmed by IR and TG studies. The trend in $g$ values $\left(g_{\|}>g_{\perp}>2.00\right)$ suggested that the unpaired electron is localized in the $d x^{2}-y^{2}$ orbital and corresponds to square planar geometry of the copper complexes. Based on these, the proposed structures are shown in Figure 4. The antimicrobial studies suggested that the Schiff bases were found to be biologically active, and their metal complexes showed significantly enhanced antibacterial and antifungal activity against microbial strains in comparison to the free ligands. Thus, exhibiting their broad spectrum nature can be further used in pharmaceutical industry for mankind, as an antimicrobial agent, after testing its toxicity to human beings.

\section{Acknowledgments}

Y. Kumar is highly thankful to University Grant Commission, New Delhi, for providing Senior Research Fellowship (SRF) and Department of Chemistry, Kurukshetra University, Kurukshetra, for providing facilities to carry out this research work. The paper was presented in the International Conference of Indian Council of Chemist, held at Bangkok in 2011. 


\section{References}

[1] Z. H. Chohan and C. T. Supuran, "In-vitro antibacterial and cytotoxic activity of cobalt (II), copper (II), nickel (II) and zinc (II) complexes of the antibiotic drug cephalothin (keflin)," Journal of Enzyme Inhibition and Medicinal Chemistry, vol. 20, no. 5, pp. 463-468, 2005.

[2] K. Singh, Y. Kumar, and R. K. Pundir, "Synthesis and characterization of biologically active organosilicon(IV) complexes with Schiff bases derived from o-aminothiophenol," Synthesis and Reactivity in Inorganic, Metal-Organic and Nano-Metal Chemistry, vol. 40, no. 10, pp. 836-842, 2010.

[3] A. Altundas, S. Nursen, N. Colak, and H. Ogutchi, "Synthesis and biological activity of new cycloalkylthiophene-Schiff bases and their $\mathrm{Cr}(\mathrm{III})$ and $\mathrm{Zn}(\mathrm{II})$ complexes," Medicinal Chemistry Research, vol. 19, no. 6, pp. 576-588, 2010.

[4] A. D. Garnovskii, I. S. Vasilchenko, D. A. Garnovskii, and B. I. Kharisov, "Molecular design of mononuclear complexes of acyclic Schiff-base ligands," Journal of Coordination Chemistry, vol. 62, no. 2, pp. 151-204, 2009.

[5] F. Heshmatpour, M. Ghassemzadeh, S. Bahemmat, J. Malakootikhah, B. Neumüller, and A. Rothenberger, "Synthesis, characterization and molecular structure of a new tetrameric palladium(II) complex containing schiff-bases derived from AMTTO (AMTTO = 4-amino-6-methyl-1,2,4-triazinethione-5-one)," Zeitschrift fur Anorganische und Allgemeine Chemie, vol. 633, no. 8, pp. 1178-1182, 2007.

[6] A. Nuria, I. Cabeza, A. Rosario, V. Y. Alvarez, K. Akdi, and M. Carretero, "Synthesis, structure and biological activity of a new and efficient $\mathrm{Cd}(\mathrm{II})$-uracil derivative complex system for cleavage of DNA," Journal of Biological Inorganic Chemistry, vol. 10, no. 8, pp. 924-934, 2005.

[7] G. Turan-Zitouni, Z. A. Kaplancikli, M. T. Yildiz, P. Chevallet, and D. Kaya, "Synthesis and antimicrobial activity of 4phenyl/cyclohexyl-5-(1- phenoxyethyl)-3-[N-(2-thiazolyl)acetamido] thio-4H-1,2,4-triazole derivatives," European Journal of Medicinal Chemistry, vol. 40, no. 6, pp. 607-613, 2005.

[8] K. Walczak, A. Gondela, and J. Suwin' ski, "Synthesis and anti-tuberculosis activity of N-aryl-C-nitroazoles," European Journal of Medicinal Chemistry, vol. 39, no. 10, pp. 849-853, 2004.

[9] A. T. Mavrova, D. Wesselinova, Y. A. Tsenov, and P. Denkova, "Synthesis, cytotoxicity and effects of some 1,2,4-triazole and 1,3,4-thiadiazole derivatives on immunocompetent cells," European Journal of Medicinal Chemistry, vol. 44, no. 1, pp. 63-69, 2009.

[10] Y. A. Al-Soud, N. A. Al-Masoudi, and A. E. R. S. Ferwanah, "Synthesis and properties of new substituted 1,2,4-triazoles: potential antitumor agents," Bioorganic and Medicinal Chemistry, vol. 11, no. 8, pp. 1701-1708, 2003.

[11] A. Almasirad, S. A. Tabatabai, M. Faizi et al., "Synthesis and anticonvulsant activity of new 2-substituted-5-[2-(2fluorophenoxy)phenyl]-1,3,4-oxadiazoles and 1,2,4-triazoles," Bioorganic and Medicinal Chemistry Letters, vol. 14, no. 24, pp. 6057-6059, 2004.

[12] M. Amir and K. Shikha, "Synthesis and anti-inflammatory, analgesic, ulcerogenic and lipid peroxidation activities of some new 2-[(2,6-dichloroanilino) phenyl]acetic acid derivatives," European Journal of Medicinal Chemistry, vol. 39, no. 6, pp. 535-545, 2004.

[13] C. D. Brandt, J. A. Kitchen, U. Beckmann, N. G. White, G. B. Jameson, and S. Brooker, "Synthesis and structures of 3,5disubstituted 1,2,4-triazole head units and incorporation of 3,5-dibenzoyl-1,2,4-triazolate into new [2 + 2] Schiff-base macrocyclic complexes," Supramolecular Chemistry, vol. 19, no. 1-2, pp. 17-27, 2007.

[14] O. Bekircan and H. Bektas, "Synthesis of new bis-1,2,4-triazole derivatives," Molecules, vol. 11, no. 6, pp. 469-477, 2006.

[15] A. I. Vogel, A Text Book of Quantitative Chemical Analysis, Longmans, Addison Wesley, London, UK, 1999.

[16] S. Bala, R. P. Gupta, M. L. Sachdeva, A. Singh, and H. K. Pujari, "Heterocyclic systems containing bridgehead nitrogen atom: part XXXIII-synthesis of s-Triazolo [3,4-b][1,3,4] thiadiazine, s-triazolo-[3,4-b][1,3,4] thiadiazino[6,7-b] quinoxaline \& as-triazino-[3,4-b] [1,3,4] thiadiazines," Indian Journal of Chemistry, vol. 16, pp. 481-483, 1978.

[17] K. R. Aneja, C. Sharma, and R. Joshi, "Fungal infection of the ear: a common problem in the north eastern part of Haryana," International Journal of Pediatric Otorhinolaryngology, vol. 74, no. 6, pp. 604-607, 2010.

[18] I. Ahmad and A. Z. Beg, "Antimicrobial and phytochemical studies on 45 Indian medicinal plants against multi-drug resistant human pathogens," Journal of Ethnopharmacology, vol. 74, no. 2, pp. 113-123, 2001.

[19] J. M. Andrews, "Determination of minimum inhibitory concentrations," Journal of Antimicrobial Chemotherapy, vol. 48, no. 1, pp. 5-16, 2001.

[20] M. I. Okeke, C. U. Iroegbu, E. N. Eze, A. S. Okoli, and C. O. Esimone, "Evaluation of extracts of the root of Landolphia owerrience for antibacterial activity," Journal of Ethnopharmacology, vol. 78, no. 2-3, pp. 119-127, 2001.

[21] S. K. S. Al-Burtamani, M. O. Fatope, R. G. Marwah, A. K. Onifade, and S. H. Al-Saidi, "Chemical composition, antibacterial and antifungal activities of the essential oil of Haplophyllum tuberculatum from Oman," Journal of Ethnopharmacology, vol. 96, no. 1-2, pp. 107-112, 2005.

[22] K. Singh, D. P. Singh, M. S. Barwa, P. Tyagi, and Y. Mirza, "Antibacterial $\mathrm{Co}(\mathrm{II}), \mathrm{Ni}(\mathrm{II}), \mathrm{Cu}(\mathrm{II})$ and $\mathrm{Zn}(\mathrm{II})$ complexes of Schiff bases derived from fluorobenzaldehyde and triazoles," Journal of Enzyme Inhibition and Medicinal Chemistry, vol. 21, no. 5, pp. 557-562, 2006.

[23] K. Singh, M. S. Barwa, and P. Tyagi, "Synthesis, characterization and biological studies of $\mathrm{Co}(\mathrm{II}), \mathrm{Ni}(\mathrm{II}), \mathrm{Cu}(\mathrm{II})$ and $\mathrm{Zn}$ (II) complexes with bidentate Schiff bases derived by heterocyclic ketone," European Journal of Medicinal Chemistry, vol. 41, no. 1, pp. 147-153, 2006.

[24] A. D. Kulkarni, S. A. Patil, V. H. Naik, and P. S. Badami, "DNA cleavage and antimicrobial investigation of $\mathrm{Co}(\mathrm{II}), \mathrm{Ni}(\mathrm{II})$, and $\mathrm{Cu}$ (II) complexes with triazole schiff base: synthesis and spectral characterization," Medicinal Chemistry Research, vol. 20, no. 3, pp. 346-354, 2011.

[25] K. Singh, D. P. Singh, M. S. Barwa, P. Tyagi, and Y. Mirza, "Some bivalent metal complexes of Schiff bases containing $\mathrm{N}$ and S donor atoms," Journal of Enzyme Inhibition and Medicinal Chemistry, vol. 21, no. 6, pp. 749-755, 2006.

[26] G. B. Bagihalli, S. A. Patil, and P. S. Badami, "Synthesis, physicochemical investigation and biological studies of zinc(II) complexes with 1,2,4-triazole schiff bases," Journal of the Iranian Chemical Society, vol. 6, no. 2, pp. 259-270, 2009.

[27] P. G. Avaji, S. A. Patil, and P. S. Badami, "Synthesis, spectral, thermal, solid state d.c. electrical conductivity and biological studies of $\mathrm{Co}(\mathrm{II}), \mathrm{Ni}(\mathrm{II})$ and $\mathrm{Cu}(\mathrm{II})$ complexes with 3substituted-4-amino (indole-3-aldehydo)-5-mercapto-1,2,4triazole Schiff bases," Journal of Coordination Chemistry, vol. 61, no. 12, pp. 1884-1896, 2008.

[28] F. A. Cotton, G. Williknson, C. A. Murillo, and M. Bochman, Advanced Inorganic Chemistry, Wiley, New York, NY, USA, 6th edition, 2003. 
[29] A. K. Patra, S. Dhar, M. Nethaji, and A. R. Chakravarty, "Metal-assisted red light-induced DNA cleavage by ternary L-methionine copper(II) complexes of planar heterocyclic bases," Dalton Transactions, no. 5, pp. 896-902, 2005.

[30] A. B. P. Lever, Inorganic Spectroscopy, Elsvier, Amsterdam, The Netherlands, 1968.

[31] A. H. Osman, M. S. Saleh, and M. M. Sanaa, "Synthesis, characterization, and photochemical studies of some copper complexes of schiff bases derived from 3-hydrazino-6methyl $[1,2,4]$ triazin-5(4H) one," Synthesis and Reactivity in Inorganic and Metal-Organic Chemistry, vol. 34, no. 6, pp. 1069-1085, 2004.

[32] O. I. Singh, M. Damayanti, N. R. Singh, R. K. H. Singh, M. Mohapatra, and R. M. Kadam, "Synthesis, EPR and biological activities of bis(1-n-butylamidino-O-alkylurea)copper(II)chloride complexes: EPR evidence for binuclear complexes in frozen DMF solution," Polyhedron, vol. 24, no. 8, pp. 909-916, 2005.

[33] Y. Anjaneyulu and R. P. Rao, "Preparation, characterization and antimicrobial activity studies on some ternary complexes of $\mathrm{Cu}(\mathrm{II})$ with acetyl acetone and various salicylic acids," Synthesis and Reactivity in Inorganic, Metal-Organic, and Nano-Metal Chemistry, vol. 16, no. 3, pp. 257-272, 1986.

[34] N. Dharmaraj, P. Viswanathamurthi, and K. Natarajan, "Ruthenium(II) complexes containing bidentate Schiff bases and their antifungal activity," Transition Metal Chemistry, vol. 26, no. 1-2, pp. 105-109, 2001. 


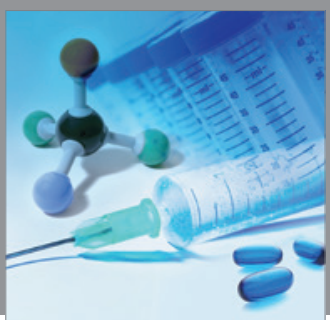

International Journal of

Medicinal Chemistry

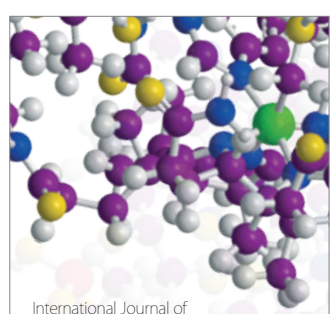

Carbohydrate Chemistry

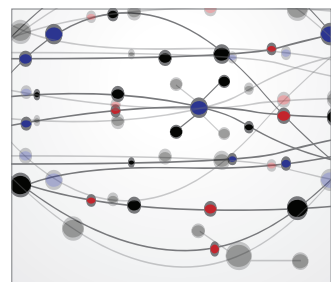

The Scientific World Journal
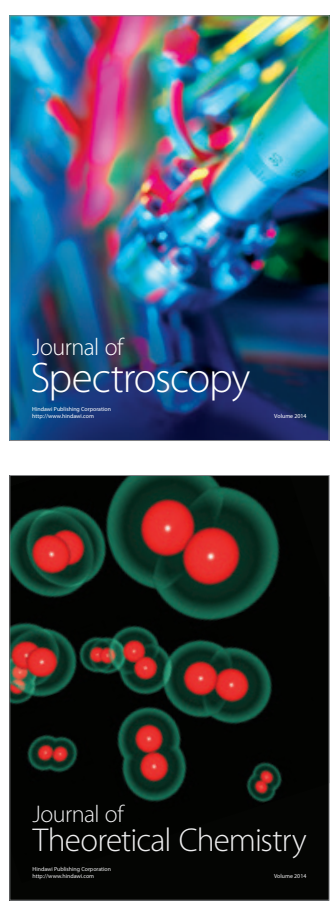
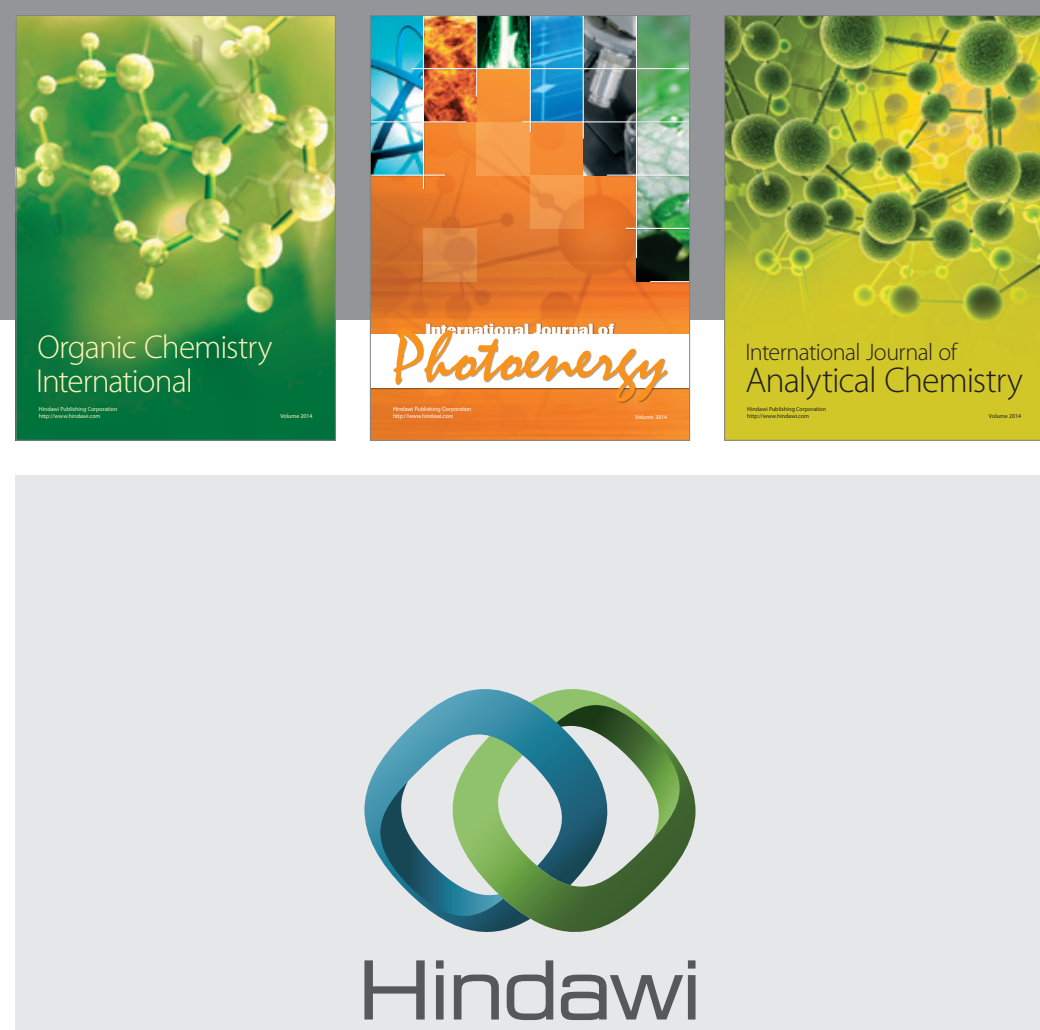

Submit your manuscripts at

http://www.hindawi.com
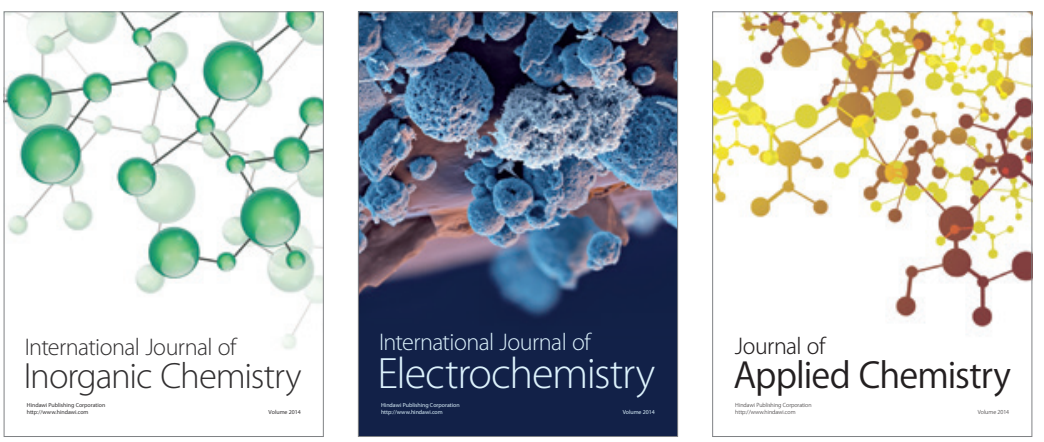

Journal of

Applied Chemistry
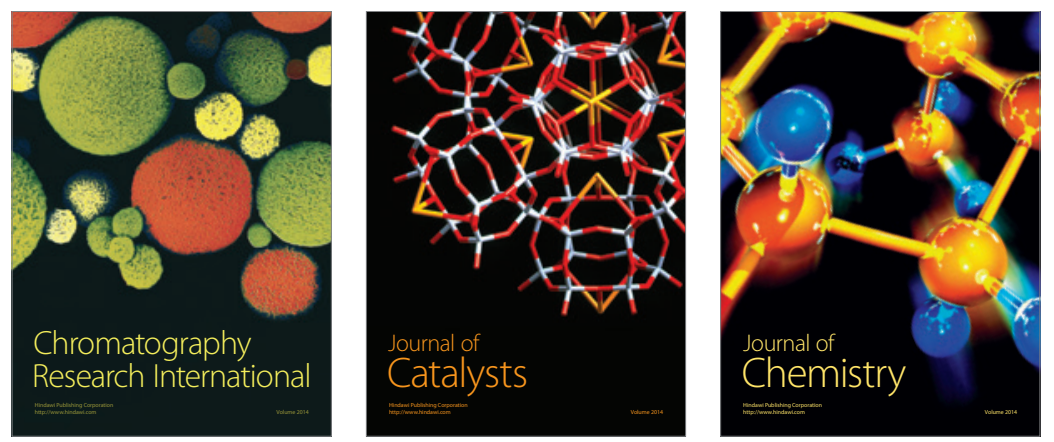
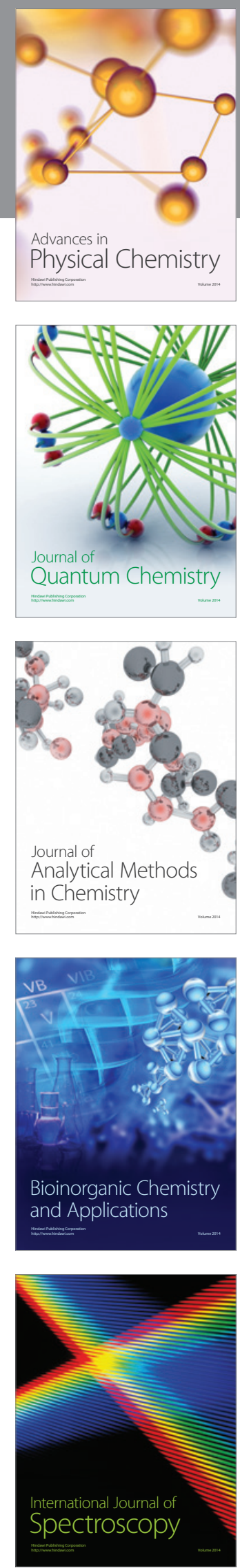